Gynecol. Invest. 1975;6:I-IV

\title{
Contents, Vol. 6, 1975
}

\section{Index}

Scientific Abstracts of the 22nd Annual Meetings of the Society for Gyne cologic Investigation, San Antonio, Tex., USA, March 20-21,1975

Seminar on Tubal Physiology and Biochemistry

Pauerstein, C.J.: Foreword 104

Chatkoff, M.L.: A Biophysicist's View of Ovum Transport 105

Blandau, R.J.; Boling, J.L.; Halbert, S., and Verdugo, P.: Methods for

Studying Oviductal Physiology 123

Coutinho, E.M.; Maia, H., jr., and Mattos, C.E.R.: Contractility of the Fallo pian Tube 146

Hodgson, B.J. and Eddy, C.A.: The Autonomic Nervous System and its Re lationship to Tubal Ovum Transport - a Reappraisal 162

Spilman, C.H. and Harper, M.J.K.: Effects of Prostaglandins on Oviductal Motility and Egg Transport 186

Ahlgren, M.: Sperm Transport to and Survival in the Human Fallopian Tube 206

Croxatto, H.B. and Ortiz, María-Elena S.: Egg Transport in the Fallopian

Tube 215

Mastroianni, L., jr. and Komins, J.: Capacitation, Ovum Maturation, Fertili

zation and Preimplantation Development in the Oviduct 226

Lipford Stone, Sarah and Hamner, C.E.: Biochemistry and Physiology of

Oviductal Secretions 234

Pauerstein, C.J.: Clinical Implications of Oviductal Physiology and Bio

chemistry 253

Zuckerman, H.; Kahana, A., and Carmel, S.: Antibacterial Activity of Human

\section{Cervical Mucus 265}

Booth, Barbara and Colas, A.E.: Binding Interactions of Progesterone and other C21 Steroids with Rat Uterine Cytosol 272

Boss, J.H.; Dishon, T., and Rosenmann, E.: Placental Antigens and Fetoproteins in the Urine of Rats - Indicators of Resorption of Conceptuses

Milewich, L.; Gomez-Sanchez, C; Madden, J.D., and MacDonald, P.C.: Isolation and Characterization of 5 $\alpha$-Pregnane-3,20-dione and Progesterone in Peripheral Blood of Pregnant

Women. Measurement Throughout Pregnancy 291

Abrams, R.M.; Thatcher, W.W.; Gwazdauskas, F.C.; Sharp, D.C.; Bazer, F.W.; Wilcox, C.J., and Stolwijk, J.A.J.: Portable Device for Vaginal

Thermal Conductance Studies $\quad 307$

Gusdon, J.P., jr.; Caudle, M.R., and Herbst, G.A.: Localization of Anti-HPL

in Fetal, Placental, and Maternal Renal Tissues 
Solash, J.; Perez, R.; Keates, J.S.; Ramasamy, N.; Stein, H.; Troyansky, D.; Ateyeh, E., jr.; Jones, J.R.; Srinivasan, S., and Sawyer, P.N.: Hormonal Steroids: Effects on the Vascular System 329

IV

Index

Karp, L.E. and Smith, W.D.: Experimental Production of Aneuploidy in Mouse Oocytes 337

Power, G.G. and Longo, L.D.: Fetal Circulation Times and their Implications for Tissue Oxygenation 341

Raju, U.; Ganguly, M.; Weiss, G.; Zarkin, A., and Levitz, M.: Serum Unconjugated Estriol in the Menstrual Cycle and Early Pregnancy 356

Pattillo, R.A. and Hussa, R.O.: Early Stimulation of Human Chorionic Gonadotropin Secretion by Dibutyryl Cyclic AMP and Theophylline in Human Malignant Trophoblast Cells in vitro: Inhibition by Actinomycin D, $\alpha$-Amanitin, and Cordycepin $\quad 365$

Book Reviews $\quad 314$

Subject Index 378

Author Index 380 